ISSN: 2238-8052

\title{
A FAZENDA ANNONI NO RIO GRANDE DO SUL: DISPUTA DE DIREITOS, LUTA PELA TERRA E AÇÃO DOS SUJEITOS
}

\author{
THE ANNONI FARM IN RIO GRANDE DO SUL: DISPUTE OF RIGHTS, CONFLICTS FOR THE LAND \\ AND ACTION OF SUBJECTS
}

Simone Lopes DICKEL ${ }^{1}$

Artigo recebido em 20/04/2019 e aceito em 27/10/2019

Palavras-chave: Fazenda Annoni, latifúndio, sujeitos, conflitos.

Keywords: Annoni Farm, landowner, subjects, conflicts.

\begin{abstract}
R E S U M O
O presente artigo debruça suas análises sobre os conflitos pela terra na fazenda Annoni na década de 1970, tendo em vista o seu papel na desapropriação do imóvel. Localizado na região Norte do Rio Grande do Sul, o antigo latifúndio foi desapropriado na década de 1970, e, embora tenha ganhado visibilidade nacional em 1985, quando ocorreu a ocupação feita por mais de 1500 famílias sem-terra, já era objeto de litígio judicial desde a década anterior. Nesse sentido, objetiva-se compreender de que modo a fazenda Annoni se tornou um espaço de conflitos pela terra a partir de diferentes sujeitos, tais como arrendatários e proprietário, e, consequentemente, objeto de decreto desapropriatório pelo poder público. Trata-se portanto, de compreender os motivos intrínsecos e extrínsecos ao imóvel, que tiveram relevância para sua desapropriação. 0 que contribui e torna possível esta análise é um documento que faz parte do grande emaranhado que integra o processo judicial de desapropriação da fazenda Annoni: um laudo pericial de 1976, cuja pretensão inicial era retratar a propriedade no contexto imediatamente anterior à desapropriação, a fim de verificar se havia ou não o cumprimento de uma função social. A esse laudo pericial estão anexadas cartas enviadas ao Presidente da República, certidões de cartórios da região atingida pela construção da barragem e estudos sobre a utilização da terra, entre outros. Uma das contribuições deste trabalho é, portanto, dar visibilidade a sujeitos que ficaram esquecidos na história do latifúndio, mas que de certa forma contribuíram para o questionamento do direito à propriedade, que culminou com o decreto desapropriatório. Tal análise será feita levando em conta as transformações que estavam ocorrendo no campo naquele contexto, que contribuíram para que latifúndio passasse a ser visto como uma contradição, especialmente diante da emergência de uma expressiva demanda por terras no estado.
\end{abstract}

\section{A B S T R A C T}

This article analyses the conflicts for land tenure of Annoni farm in the 1970s, owing to its role in the property expropriation. Located in the northern region of Rio Grande do Sul, the old estate was expropriated in the 1970s and although it received nationwide visibility in 1985, when it was occupied by 1500 landless families, it has been the subject of judicial litigation since the previous decade. In this sense, the objective is to understand how the Annoni farm became a space of conflicts over the land from different subjects, such as renters and owners and, consequently, an object of expropriation decree by the public power. It is therefore a matter of understanding the intrinsic and extrinsic motives related to the property which were relevant for its expropriation. What contributes and makes this analysis possible is a document that is

\footnotetext{
1 Doutoranda em História pelo Programa de Pós Graduação em História da Universidade de Passo Fundo. Mestre em História pelo Programa de Pós Graduação em História da Universidade de Passo Fundo. Graduada em História - Licenciatura Plena, pela Universidade de Passo Fundo (2009). Professora de História da Rede Pública Estadual do Rio Grande do Sul. Integrante do Núcleo de Estudos em História do Mundo Rural (NEHMUR), vinculado à Linha de Pesquisa Espaço, Economia e Sociedade do PPGH da Universidade de Passo Fundo. E-mail: simone.lopes.dickel@gmail.com.
} 
part of a great tangle that integrates the judicial expropriation process of the Annoni farm: a 1976 expert report which initial claim was to portray property context immediately prior to expropriation to verify whether or not a social function was fulfilled. Letters sent to Brazil's President, notary's certificates from the region hit by the dam construction and land use studies among other documents were attached to this expert report. One of the contributions of this work is to give visibility to subjects who have been forgotten in the history of the landownership but that somehow contributed to the question of the right to property, which culminated with the expropriation decree. This analysis will be done taking into account the transformations that were taking place in the rural space in that context that contributed to the farm becoming seen as a contradiction, especially given the emergence of a significant demand for land in the state of Rio Grande do Sul.

\section{INTRODUÇÃO}

Antes mesmo de contextualizar a fazenda Annoni, denotando sua importância histórica no que se refere aos conflitos pela terra e a reforma agrária no Brasil, é importante situá-la no contexto regional, o que contribui de forma significativa para compreender seu histórico de conflitos. Anteriormente ao domínio de Ernesto José Annoni, a área, que inicialmente compreendia mais de 16 mil hectares, integrava um grande latifúndio regional, cuja origem remonta ao início do segundo reinado, antes mesmo de a Lei de Terras (1850) definir a compra como forma de acesso à terra. Era a fazenda Sarandi, situada no norte do Rio Grande do Sul, latifúndio que chegou a compreender 70 mil hectares na região onde hoje fica parte do município de Sarandi e de municípios circunvizinhos.

Em um processo que não destoa da forma como se configurou de um modo geral a apropriação territorial do solo brasileiro desde a chegada dos portugueses, o domínio de poucas famílias sobre a terra representou a restrição do seu acesso a muitas famílias, também na região da fazenda Sarandi. De um modo especial, a Lei de Terras (1850) contribuiu para a manutenção desse padrão, dificultando o acesso à terra por parte dos imigrantes e negros libertos, resultando em um grande nível de desigualdade no acesso à terra (STÉDILE, 2005). Poucos com muito, e muitos com pouco. Na medida em que se escancara a profunda disparidade na estrutura fundiária, problemas decorrentes dela tornam-se cada vez mais frequentes. Aos poucos, a massa camponesa em situação de miséria se vê na condição de resistir à exploração e à expropriação, dando origem a conflitos pela terra, que marcaram profundamente a história da região da fazenda Sarandi.

Desmembrada desse grande latifúndio regional, a fazenda Annoni teve sua história caracterizada pela luta pelo direito à terra. $\mathrm{E}$ a disputa por esse direito não se resume apenas à grande ocupação protagonizada pelas milhares de famílias sem-terra em 1985, embora tenha sido ela que deu grande visibilidade ao latifúndio e ao drama dos sem-terra (TAVARES, 2009). 0 questionamento ao direito à propriedade na Annoni é anterior, e pouco conhecido do grande público. Desapropriado desde 1972, portanto, durante o governo Médici (1969-1974), o imóvel rural era objeto de um complexo litígio judicial que colocava de um lado a família desapropriada reclamando o direito à 
propriedade, e, do outro, o Incra, autarquia federal que representava os interesses da União, amparado pelo princípio da função social para intervir no direito à propriedade (DICKEL, 2017).

Nesse sentido, busca-se, neste trabalho, compreender os elementos motivadores da desapropriação, os quais, embora estejam relacionados, serão divididos em dois grupos. 0 primeiro deles tem relação com a estrutura fundiária da região, o esgotamento da fronteira agrícola e o encarecimento das terras, a minifundização, e, principalmente, a existência de uma "tensão social" no imóvel em questão. Esses são fatores intrínsecos ao imóvel, que contribuem para que ele seja desapropriado de acordo com a fonte analisada, o laudo pericial. 0 segundo elemento, por sua vez, não tem relação direta com o imóvel em si, mas sim com o contexto da época no qual ocorre o surgimento de uma demanda por terras no Rio Grande do Sul, em decorrência dos desalojamentos motivados pela construção de barragens. Para solucionar essa demanda, a Annoni, em virtude também dos outros fatores, foi apontada como alternativa.

Para fins de organização do texto, propõe-se, em uma primeira seção, contextualizar o latifúndio e a estrutura fundiária da região, bem como as formas de exploração das terras, e, relacionado a esta, apresentar a existência de conflitos internos no imóvel; e, em uma segunda seção, mostrar como parte desse mesmo projeto do estado de modernização econômica - a construção de barragens - faz surgir uma demanda por terras no estado que é usada como elemento propulsor da desapropriação.

\section{A FAZENDA ANNONI NA DÉCADA DE 1970: ESTRUTURA FUNDIÁRIA REGIONAL E A EXISTÊNCIA DE UMA “TENSÃO SOCIAL” NO IMÓVEL}

Na década de 1940, a fazenda Annoni passou para o domínio de Ernesto José Annoni, passando a ser denominada oficialmente "fazenda Sarandi-Annoni" (BONAVIGO; BAVARESCO, 2008, p. 33), uma referência ao grande latifúndio regional do qual fazia parte e também ao sobrenome da família proprietária. Boa parte das terras era destinada à exploração florestal e à pecuária extensiva, práticas comuns na região e que, na época, proporcionavam lucros satisfatórios à família proprietária (DICKEL, 2017). Afora essas atividades, para as quais contribuíam alguns empregados que residiam na fazenda, o imóvel também era explorado indiretamente, por granjeiros que arrendavam áreas de terra, além de colonos que exploravam pequenas colônias de terras em regime de parceria.

As informações que dão visibilidade a esses sujeitos sobre os quais, até então, praticamente não havia conhecimento, foram encontradas em relatórios contidos em um laudo pericial datado de 19762. Esse documento é apenas um dos vários estudos técnicos demandados ao longo do litígio no

\footnotetext{
2 Esse laudo pericial, datado de 1976, pretendia retratar a situação do imóvel à época da sua desapropriação. Nele, constam diversos questionamentos sobre o aproveitamento econômico do imóvel, além de muitas outras informações que permitem analisar o cumprimento da função social do imóvel em questão. Ele compõe, junto com vários documentos anexados, parte do
} 
qual a propriedade da Annoni era disputada na justiça pela família Annoni e pelo Incra e referia-se ao status do imóvel à época de sua desapropriação em 1972.

Ocorre que, oficialmente, o imóvel estava cadastrado como "latifúndio por exploração", categoria definida pelo Estatuto da Terra (Lei no 4.504 de 30 de novembro de 1964) sobre a qual o ato desapropriatório poderia ter incidido, como de fato aconteceu. Amparada no Estatuto da Terra, que previa a desapropriação de latifúndios para fins de reforma agrária, a União baixou o decreto no 70.232. No entanto, a defesa da família desapropriada contestou a ação de desapropriação movida pela União, alegando que esse cadastro estava obsoleto 3 e não correspondia à realidade do imóvel, que, seguramente, segundo eles, poderia ser classificado como empresa rural, sendo, portanto, imune à desapropriação.

Esse laudo pericial de 1976 dá conta da existência de certa "tensão social" que, de um lado, tinha esses sujeitos que exploravam parte das terras e, de outro, o proprietário ${ }^{4}$, o que teria contribuído para a indicação da desapropriação do imóvel, a fim de solucionar a necessidade de terras para reassentamento de rurícolas no estado. Mas, para que se compreenda o teor desses conflitos, é importante primeiramente conhecer as principais formas de cessão das terras, uma vez que a "tensão social" se dava principalmente entre o proprietário e alguns de seus arrendatários. Tal divisão entre as diferentes formas de exploração, bem como os conflitos que permeavam as relações sociais no imóvel, aparecem especificados em um relatório do Instituto Gaúcho de Reforma Agrária (Igra) elaborado em 1970. Anexado ao laudo pericial em questão, o relatório é denominado "levantamento dos tipos de exploração das terras de Ernesto José Annoni - Município de Sarandi-RS".

Enquanto a maior parte do imóvel era destinada à pecuária extensiva, desenvolvida pelo proprietário e alguns empregados sobre os quais há algumas poucas referências no documento, cerca de aproximadamente um terço da área explorável era utilizada para a produção de grãos, como milho, em menor quantidade, e também trigo ${ }^{5}$ e soja, através da cessão de terras a terceiros, mediante pagamento de arrendamentos. As formas de cessão de terras eram: por prestação de serviço, sem

grande e confuso processo judicial de desapropriação da fazenda Annoni, que teve início no começo da década de 1970 com o decreto de desapropriação, percorrendo as décadas seguintes, chegando até os dias atuais, quando há ainda questionamentos em relação à indenização entre os herdeiros. Está localizado no Incra/RS, em Porto Alegre, em uma das muitas caixas que guardam os volumes nos quais o processo se desdobrou em função da sua complexidade.

3 A última revisão cadastral do imóvel é datada de 1966. De acordo com o Estatuto da Terra, é de responsabilidade do proprietário manter o cadastro atualizado, informando o estado sobre qualquer modificação no status da propriedade rural. ${ }_{4} 0$ maior conflito que se deu entre o proprietário e um desses arrendatários em decorrência de ação judicial foi parar até no jornal. 0 jornal “O Estado de São Paulo" publicou, em 10/07/1986 (p. 14), quase um ano após a grande ocupação feita pelos sem-terra, uma reportagem dedicada a entender a "questão Annoni". A reportagem, cujo título é "Fazenda Annoni, uma questão pessoal", deixa clara a existência de conflito entre proprietário e um dos arrendatários. De acordo com o jornal, o arrendatário em questão possuía uma relação de amizade com o Bispo de Passo Fundo, o qual interviu diante da ação que almejava o despejo do arrendatário, através de correspondência ao Presidente da República Emílio G. Médici, na qual ele recomenda que a Annoni seja desapropriada. Tal reportagem corrobora com as considerações feitas a partir da análise da fonte trabalhada.

5 Embora um dos documentos afirme que o proprietário foi um dos pioneiros na produção tritícola na região, as áreas arrendadas dedicavam uma porcentagem maior à produção do grão do que a área explorada pelo proprietário. 
contrato, com contrato (áreas em litígio), e ainda havia o sistema de parceria com os colonos, já referido anteriormente.

A primeira forma de exploração, a cessão das terras por prestação de serviço, consistia no preparo do terreno e plantio de uma determinada área de terras determinada pelo proprietário no período de um ano. Ao final desse período, os arrendatários deveriam entregar as terras ao proprietário, havendo a possibilidade de conseguir novas áreas na propriedade. 0 caráter provisório da ocupação e a própria natureza precária do contrato não permitiam a construção de benfeitorias e nem mesmo a realização de investimentos como correção do solo, o que resultava em uma menor produtividade e, consequentemente, menor lucratividade aos prestadores de serviço, que empenhavam trabalho e capital na produção agrícola. Sem maiores perspectivas de lucros, alguns desses prestadores de serviço já haviam manifestado o desejo de desistir da atividade agrícola tão logo encontrassem outras terras para cultivar.

Com relação à exploração sem contratos, há poucas informações. Já em relação às áreas arrendadas mediante contrato de parceria, os conflitos protagonizados por esses sujeitos ocupam um espaço expressivo no laudo pericial, o que deixa claro o interesse do documento em asseverar a existência desses conflitos enquanto elemento propulsor do interesse público em desapropriar o imóvel. Isso se dá em contraposição ao argumento dos desapropriados na época de que o decreto seria uma espécie de retaliação, "tendo sido motivado por questões políticas e pessoais" (DICKEL, 2017, p. 71). Ao que fica evidente, os arrendatários - pelo espaço social que ocupavam e pela relevância das atividades que desenvolviam no imóvel - angariaram uma série de relações sociais em seu favor, a fim de ter parte de suas demandas atendidas. São exemplos disso cartas enviadas por cooperativas da regiãos solicitando intervenção das autoridades na questão judicial entre os arrendatários e o proprietário, em favor de seus associados.

Em uma das cartas, intervindo em favor de um dos seus associados, uma das cooperativas solicitou a intervenção das "altas autoridades da república" na questão judicial movida pelo proprietário contra um dos arrendatários. Segundo o proprietário, que moveu ação de reintegração de posse, o arrendatário não estaria cumprindo plenamente as cláusulas do contrato de parceria assinado anos antes e renovado, e, por esse motivo, ele estava tentando judicialmente retomar a área cedida e em posse do arrendatário. Em favor de seu associado, a cooperativa afirma que, no caso de se concretizar o despejo, o arrendatário teria prejuízos "inabsorvíveis", o que seria inadmissível, uma vez que ele "canoniza toda sua produção na cooperativa" e movimenta "somas expressivas" de capital, contribuindo para o desenvolvimento regional.

O espaço social ocupado por esses sujeitos e a importância que acabam adquirindo no processo histórico ajudam a identificar as mudanças que estavam ocorrendo no campo naquela época, nas quais eles ocupam um espaço central. Esse processo de modernização da atividade agrícola leva à consequente transformação dos latifúndios em empresas rurais e faz com que a agricultura passe a 
receber um "tratamento empresarial", mediante investimentos e inovações tecnológicas, já estava previsto no Estatuto da Terra (Lei no 4.504 de lei no 4.504, de 30 de novembro de 1964). Tal processo, parte de um projeto de estado da época, pode ser compreendido como uma via conservadora pela qual o estado brasileiro tenta, embora sem sucesso, resolver os problemas do campo sem precisar modificar a estrutura fundiária. Conforme Regina Bruno (1997), com a possibilidade de modernização mediante incentivos como o crédito rural, cria-se uma espécie de "brecha escapatória", o que significa, de certa forma, uma continuidade para o latifúndio.

Para a consecução de tal propósito, expresso implicitamente no Estatuto da Terra, o estado brasileiro concedeu proteção judicial às empresas rurais (LUZ, 1996) como uma forma de estimular a modernização do latifúndio, a fim de romper com a imagem do "atraso" associada a esse contexto. 0 aumento da produção e da produtividade agrícola mediante o uso de novas tecnologias e métodos mais "racionais" de exploração do solo também constituía princípios que norteavam a política agrícola do período, harmonizando a utilização da terra "com o processo de industrialização do país" (Lei no 4.504 de 30 de novembro de 1964).

A respeito desse processo de transformação do latifúndio em "empresa rural", há uma grande controvérsia no processo de desapropriação da fazenda Annoni, já que, oficialmente, o imóvel era um latifúndio por exploração. Mas de acordo com a defesa dos desapropriados, essa classificação estava ultrapassada, sendo "empresa rural" a categoria que melhor definia o imóvel à época da sua desapropriação. Por isso, a modificação do cadastro do imóvel, possibilitada pelo decreto 70.231 de 3 de março de $1972^{6}$, poderia reverter o processo desapropriatório (DICKEL, 2017, p. 63), já que, conforme visto, aos olhos da lei, as empresas rurais eram protegidas por representarem um modelo de propriedade adequada ao projeto econômico do estado brasileiro na época.

E assim, a comprovação de ser a Annoni legalmente uma empresa rural foi pleiteada durante os primeiros anos em que tramitou o processo judicial de desapropriação, representando uma forma de resistência da família à perda da propriedade (DICKEL, 2017). Contraditoriamente, para alcançar os coeficientes e resultados relativos à produção e à produtividade de modo a atender critérios estabelecidos previamente em lei, a família proprietária contabilizou a área trabalhada pelos arrendatários, cujo caráter empresarial da exploração agrícola pode ser constatado no laudo pericial. Além do uso de implementos modernos pelos arrendatários, a priorização da agricultura em substituição à pecuária e a movimentação de grandes somas em investimentos feitos na lavoura, que é ratificada pelas cooperativas das quais eles eram associados e nas quais confiavam toda a produção

\footnotetext{
60 decreto no 70.231 ordenava que fossem revisados os cadastros dos imóveis rurais em todo o território nacional, para o qual fixava prazos, conforme se vê no seu art. 1ㅇ: A revisão geral do cadastro rural, a que se refere o $\S 4^{\circ}{ }^{\circ}$ do artigo 46 da Lei $n^{\circ}$ 4.504, de 30 de novembro de 1964, será realizada pelo Instituto Nacional de Colonização e Reforma Agrária, em todo o território nacional, no período de 15 de março a 15 de junho de 1972, de acordo com os prazos fixados para cada região em Instrução do Incra aprovada pelo Ministro da Agricultura (Decreto no 70.231 de 3 de março de 1972). Baixado na mesma data do Decreto no 70.232, que declarou a Annoni de interesse social para fins de desapropriação, esse decreto contribuiu para complexificar o processo, uma vez que permitiu a revisão do cadastro da Annoni.
} 
agrícola, caracterizavam um modelo produtivo que atendia aos interesses do estado brasileiro na época.

O que torna esse contexto contraditório - embora fosse permitida em lei a contabilização da produção auferida pelos arrendatários para a comprovação do pertencimento da Annoni à categoria "empresa rural" - é o fato de existirem conflitos entre aqueles que exploravam as terras mediante pagamento de arrendamentos e o proprietário. 0 primeiro conflito de direitos relacionado à Annoni se deu entre aquele que detém a propriedade do imóvel e que, no seu direito de proprietário, pretendeu retomar a posse concedida a terceiros, e aqueles que detêm a sua posse, conquistada mediante contrato e legitimada pela forma de exploração das terras.

Olhando do ponto de vista da exploração econômica, havia dois modelos de exploração agrícola. 0 primeiro deles assentava-se nos moldes preconizados pela "revolução verde"7, a partir do uso de implementos modernos que permitiam um melhor aproveitamento da capacidade produtiva do imóvel (ALVES, 2013). Os arrendatários figuravam como representantes desse novo modelo que estava se sobrepondo ao anterior, com a anuência do Estado, através da produção predominantemente de trigo e soja. Já o outro modelo, desenvolvido pelo proprietário, centrado na exploração florestal e na pecuária extensiva, representava um modelo produtivo que estava sendo suplantado por uma nova agricultura, mais moderna, consumidora de novas tecnologias e alinhada aos interesses do grande capital e da indústria.

O discurso dos tribunais diante dos relatórios e estudos técnicos produzidos e apresentados foi favorável à classificação do imóvel como empresa rural. Concordando com a existência de um "caráter empresarial" que revestia a exploração da terra no imóvel, muitos dos ministros usaram os bons resultados alcançados pela pecuária para justificar seu posicionamento. No entanto, é preciso pontuar que a pecuária é uma atividade que tem um impacto econômico muito menor para a região, em pouco contribuindo para o seu desenvolvimento, ainda mais se considerarmos que esse era um contexto no qual havia incentivos por parte do Estado brasileiro para que o campo se integrasse ao novo modelo de desenvolvimento econômico, através da sua modernização (ALVES, 2017). Essa é uma das razões que justifica, por exemplo, o parecer de cooperativas da região em favor dos arrendatários, solicitando intervenção das autoridades em uma ação em que o proprietário queria a reintegração de posse da área. A entidade cumpre, portanto, com seu papel de procurar auxiliar e defender os interesses de seus associados, intervindo publicamente em favor deles.

Eram três os arrendatários que possuíam contrato de parceria e exploravam áreas maiores de terras, e todos haviam entrado em conflito com o proprietário. Dois deles recorreram ao apoio de cooperativas, sindicatos e personalidades influentes na época, como é o caso do Bispo de Passo Fundo,

\footnotetext{
7 Nome pelo qual ficou conhecido o conjunto de transformações decorrentes do processo de penetração do capital no campo, com a sua consequente modernização e integração ao projeto de desenvolvimento econômico nacional. A aquisição de implementos mediante o crédito agrícola e a canalização da produção nas chamadas cooperativas são parte importante desse processo (ALVES, 2013).
} 
Cláudio Cooling, que, assim como as entidades citadas, enviou carta ao presidente Médici solicitando intervenção na questão da Annoni. A produção agrícola dessas áreas somadas era superior ao que era produzido em uma área bem maior, explorada pelo proprietário. Isso, de certa forma, contribuiu para que eles recebessem apoio de diferentes setores da sociedade, na disputa de direitos sobre a terra travada entre eles e o proprietário.

Com relação à interferência sindical referente à "tensão social" denunciada pelo Bispo Cláudio Cooling, os Sindicatos dos Trabalhadores Rurais de Sarandi, Rondinha e Constantina, conjuntamente, também enviaram uma carta ao presidente Médici. Apesar de relativamente consolidada no ambiente acadêmico uma visão acerca da inércia que teria revestido a ação dos sindicatos durante o regime militar, a carta mostra um aspecto interessante acerca da ação dos sindicatos, que é a recomendação para o cumprimento da lei. Afinal, foi o próprio regime militar que previu em lei a realização da reforma agrária, um dos pilares sobre os quais se assentava o Estatuto da Terra, elaborado logo que Humberto de Alencar Castello Branco assumiu o poder. Logo, apesar de a repressão que caracterizou o período militar ter atingido também os sindicatos e suas lideranças, cuja ação foi engessada, tornandose restrita, não havia nada de tão revolucionário ou subversivo em cobrar do governo o cumprimento da lei que ele mesmo criou.

A carta inicia com um tom enfático, lembrando "ser o propósito do governo resolver gradativamente os problemas sociais no meio rural sob a bandeira da reforma agrária justa no país". Propositalmente, o texto da carta faz referência à legislação, dando ênfase a um dos objetivos manifestos no Estatuto da Terra, que é a realização da reforma agrária. No art. 1o, $\S 1$, a reforma agrária está definida como "o conjunto de medidas que visem a promover melhor distribuição da terra, mediante modificações no regime de sua posse e uso, a fim de atender aos princípios de justiça social e ao aumento de produtividade" (Lei no 4.504, de 30 de novembro de 1964).

A carta reforça, ainda, o caráter empresarial das atividades desenvolvidas pelos arrendatários, "homens de grande projeção no mundo dos negócios e maiores triticultores do município", em contraposição à figura do proprietário, lembrado no documento como alguém "ávido pelo recebimento dos arrendamentos". No entanto, essa carta assume um direcionamento marcado pelo sentido de ressaltar a contradição que representava uma grande propriedade em uma região onde o minifúndio configurava-se um problema, uma vez que ele é um obstáculo à reprodução social dos pequenos proprietários, impossibilitados de tirar da terra o sustento do grupo familiar, o que contribui em grande parte para o êxodo rural, que se mostra uma preocupação recorrente naquele contexto.

Essa mesma carta, remetida ao presidente Médici em 1970, ao final, “apela que seja desapropriada urgentemente a fazenda de Ernesto José Annoni, bem como tantas quantas necessárias para a colocação dos nossos trabalhadores rurais sem terra a fim de que possamos viver a paz social e o progresso do nosso imenso e amado torrão brasileiro" (Carta dos Sindicatos dos Trabalhadores Rurais de Sarandi, Rondinha e Constantina, 1970 - Laudo Pericial de 1976). 
A orientação para o cumprimento da legislação que prevê a realização da reforma agrária através das desapropriações de terras, no caso o Estatuto da Terra, retrata o posicionamento dos sindicatos em relação à contradição que o latifúndio representa naquele contexto. Palco de uma tensão social, localizado em uma região onde não havia mais fronteira agrícola a ser explorada, a terra estava encarecendo, e as pequenas propriedades já não davam conta do aumento populacional, aumentando o contingente de sem-terra. A reforma agrária é, nesse contexto, apontada como alternativa a fim de condicionar o imóvel a uma função social. Além de se tornar "mais produtiva", a terra passaria a cumprir uma função social, possibilitando trabalho e uma vida digna a centenas de famílias em situação aflitiva oriundas da própria região do imóvel, ou mesmo de fora dela.

A recomendação de que fosse realizada a reforma agrária nas terras da Annoni também aparece em outro documento, que resultou de um encontro de lideranças rurais no mesmo período na região da fazenda Sarandi. Ambos preveem tal ação como solução ao impasse existente na região, que é a existência ao mesmo tempo de muitas famílias com pouca terra, tendo sua capacidade produtiva limitada em função da quantidade de terras, que é insuficiente, e do grande latifúndio, que poderia proporcionar trabalho e moradia a tantas famílias necessitadas, como é o caso dos próprios empregados e dos colonos que trabalham em pequenas áreas de terra na própria fazenda Annoni.

Essa característica pujante da estrutura fundiária da região, historicamente ocupada por índios, caboclos, imigrantes, madeireiros e ainda por grandes fazendas de gado, e tendo como componente marcante do seu processo de ocupação a figura do pequeno agricultor, seja ele colono ou caboclo (MACHADO et al., 2018), contribuiu para o surgimento de um contingente expressivo de famílias sem-terra ainda na década de 1960. Para solucionar parte desse problema, em 1962, o governador Leonel Brizola, pressionado por uma ocupação feita pelo Movimento dos Agricultores Sem Terra (Master), desapropriou a fazenda Sarandi ${ }^{8}$, latifúndio-mãe do qual a Annoni foi desmembrada. No entanto, tal ação paliativa não resolveu o problema da falta de terras, agravado nos anos seguintes pela modernização do campo (MARCON, 1997).

Diante desse contexto, a forma como o direito à propriedade estava sendo exercido na Annoni no início da década de 1970 passou a ser alvo de questionamentos, destoando dos interesses da coletividade, prejudicando famílias que, embora vivessem do trabalho naquelas terras, fazendo-as produzir, não possuíam a segurança jurídica que a condição de proprietário proporciona, seja para fazer mais investimentos, no caso dos arrendatários, seja para continuar suprindo as necessidades da família com o trabalho na terra, no caso dos colonos parceiros. Ambos os sujeitos, embora fossem privados da propriedade do imóvel, usufruindo da sua posse, faziam o imóvel produzir. Enquanto as famílias de colonos trabalhavam principalmente para a sobrevivência do grupo familiar, os

\footnotetext{
8 Sobre a desapropriação da fazenda Sarandi, ver ALVES, B.J.P. A política agrária de Leonel Brizola no Rio Grande do Sul: governo, legislação e mobilização. Mestrado. Programa de Pós-Graduação de Ciências Sociais em Desenvolvimento Agricultura (Universidade Federal Rural do Rio de Janeiro, UFRRJ, Brasil) 2010; e MARCON, Telmo. Acampamento Natalino: história da luta pela reforma agrária. Passo Fundo: Ediupf, 1997.
} 
arrendatários investiam uma soma maior de capital, que se reproduzia, circulando e sendo reinvestido na produção agrícola.

0 exercício do direito à propriedade da Annoni estava trazendo problemas aos arrendatários, que, apesar da grande soma de investimentos para plantar parte das terras, entraram em disputa judicial com o proprietário, pelejando pelo direito de permanecer na área cultivada. No caso dos demais parceiros, eram vinte famílias de colonos que cultivavam pequenas colônias de terras, pagando com parte da produção. À medida que as famílias iam crescendo, também passavam por dificuldades, e cada vez mais enfrentavam incertezas em relação à sua permanência no imóvel, habitual de quem trabalha em terras alheias.

Em uma região marcada pelo predomínio de pequenas propriedades, que não se reproduzem e onde "se labuta com dificuldades próprias da vida no campo para garantir a sobrevivência", em uma época em que a mecanização e a falta de terras para explorar encarecem as terras e impulsiona o êxodo rural, que se torna uma preocupação também das cidades, é compreensível que um latifúndio como a Annoni passe a ser visto como uma incoerência. 0 direito à propriedade, da forma como estava sendo exercido, se torna motivo de questionamentos. Ele passa, então, a se configurar como uma contradição diante da existência de cerca de pelo menos mil famílias sem-terra, segundo levantamento realizado na região do próprio imóvel, conforme cita o laudo pericial. Assim, aos poucos, a desapropriação do imóvel ganha apoiadores.

Embora os proprietários tenham buscado na constituição o amparo ao seu direito à propriedade, é pertinente lembrar que esse já não corresponde mais a um direito absoluto, pois está condicionado ao cumprimento de uma função social. A função social, princípio norteador para o exercício do direito à propriedade, é especificada pela primeira vez no Estatuto da Terra (lei no 4.504, de 30 de novembro de 1964), incorporado mais de duas décadas depois na atual Constituição (CF, 1988). Um dos quesitos para que a propriedade da terra cumpra com sua função social é o de que o seu uso seja em benefício não apenas dos proprietários, mas também "daqueles que nela labutam" (BRASIL, CONSTITUIÇÃO, 1988).

Uma análise mesmo que simplória das relações sociais entre os sujeitos já referidos sinaliza problemas no cumprimento desse quesito, o que, por si só, na letra da lei, bastaria para que o imóvel fosse desapropriado, pois sua função social não estava sendo cumprida plenamente. Sabe-se, no entanto, que os interesses ligados ao latifúndio também se fizeram presentes na elaboração do Estatuto da Terra, e uma das marcas deixadas por essa intervenção é a proteção às empresas rurais (LUZ, 1996), possibilitando a resistência do latifúndio mediante sua modernização. 0 recadastramento do imóvel com a possibilidade de classificá-lo como uma empresa rural passou a ser pleiteado pela defesa da família Annoni tão logo foi baixado o ato desapropriatório assinado pelo presidente Médici. No entanto, a existência de uma demanda externa ao latifúndio contribuiu para que sua desapropriação fosse priorizada pelo poder público. Havia um novo problema social a resolver: os 
desalojados pela construção da barragem do Passo Real, fator externo ao imóvel em si, mas que contribui para sua desapropriação.

\section{A CONSTRUÇÃo DE BARRAGENS NO RIO GRANDE DO SUL NO FINAL DA DÉCADA DE 1960 E 0 SURGIMENTO DE UMA DEMANDA POR TERRAS}

Uma das alavancas para o chamado "milagre brasileiro" no final da década de 1960, a mudança do perfil produtivo do setor primário para o setor industrial, fazia parte do projeto de estado preconizado pelos militares que assumiram o comando do país a partir do golpe civil militar de 1964 . Para que essa modernização da economia fosse efetivada, impulsionando a industrialização, se fazia necessária a ampliação da matriz energética, através da construção de usinas hidrelétricas, que passam a constituir uma espécie de pré-requisito para o desenvolvimento econômico (SEMINOTTI, 2008, p. 131).

De acordo com Seminotti (2008, p. 131), o sul do Brasil apresentava condições propícias à geração de energia elétrica, uma vez que se trata de região rica em bacias hidrográficas. Nesse cenário, tem destaque especial a Bacia do Rio Uruguai, o que se justifica em razão das condições naturais, como "relevo acidentado e grandes vales". Nesse intuito, na região de Cruz Alta, Espumoso e Ibirubá, região central do Rio Grande do Sul, o rio Jacuí foi represado para a construção da Barragem do Passo Real, originando o maior lago artificial do estado 9 .

No entanto, o suprimento da crescente demanda por energia elétrica decorrente do modelo econômico que tinha a indústria como "carro chefe", que motivou a construção de barragens e seus respectivos reservatórios nas diversas regiões do país, teve também seu aspecto negativo. 0 impacto social da construção de barragens, tema que cada vez mais tem despertado o interesse, especialmente da área das ciências humanas, se fez sentir na região da construção da Barragem do Passo Real, e centenas de famílias tiveram de ser removidas de suas terras, as quais foram atingidas por um decreto de desapropriação por utilidade pública. Segundo o decreto no 3.365/41, a desapropriação por utilidade pública ocorre quando há a necessidade do poder público de desapropriar um imóvel para a construção de uma obra que beneficiará a sociedade em geral, como é o caso da construção das hidrelétricas, já que a produção de energia elétrica passou a ser vista como um imperativo para o desenvolvimento regional.

Ainda de acordo com o decreto $\mathrm{n}^{-}$3.365/41, a indenização das famílias atingidas pela construção da barragem ficaria a cargo da Companhia Estadual de Energia Elétrica (CEEE), empresa responsável pelo planejamento e pela execução do projeto, que alegou não dispor dos meios necessários para resolver o problema dos "afogados", alcunha pela qual ficaram conhecidas essas

\footnotetext{
${ }^{9}$ Em 2018, em virtude dos cinquenta anos da construção da Barragem do Passo Real, o jornal Zero Hora fez uma série de reportagens relembrando a história da construção de uma das maiores obras de engenharia do estado.
} 
famílias atingidas pela construção da barragem do Passo Real. Isso aconteceu porque, além de o valor ofertado em termos de indenização ser insuficiente para a aquisição de novas terras, a forma de ocupação das propriedades em muitos casos não fazia jus ao direito de indenização, uma vez que muitos que ali residiam eram posseiros, meeiros, arrendatários ou filhos de proprietários (SEMINOTTI, 2008). Isso não significa, de forma alguma, que eles não tenham sido "atingidos em cheio" pela construção da barragem.

A construção da Barragem do Passo Real determinou a inundação de cerca de 23 mil hectares de terras, pertencentes aos municípios de Espumoso, Cruz Alta, Ibirubá e Selbach, onde residiam aproximadamente 1.600 famílias de agricultores, dentre as quais 1050 optaram por novas terras. Essa situação se torna um verdadeiro problema, um problema coletivo, que passa então a ser responsabilidade do estado, uma vez que muitas famílias foram coagidas pelo estado a sair das terras onde vivam, muitas delas há décadas, e até gerações, sem ter para onde ir. Mesmo aquelas que faziam jus à indenização demorariam a conseguir reorganizar suas vidas longe dali. Torna-se necessário, então, ao Estado brasileiro, encontrar terras para reassentar essas famílias, não muito distante da região de origem.

Para atender a tal demanda, o Incra desapropriou 16.449,36 hectares de terra nos municípios de Cruz Alta, Ibirubá e Santa Bárbara do Sul, beneficiando 528 famílias, com o "Projeto Integrado de Colonização do Passo Real”. Para as famílias que não haviam sido contempladas nessa primeira etapa, o Incra providenciou novas áreas, desapropriando a Invernada do Butiá, pertencente à SagrisaComercial e Agrícola Ltda, distante cerca de quarenta quilômetros de Sarandi, a fazenda SarandiAnnoni, e também parte da ex-Estação Experimental Engenheiro Luiz Englert-Sertão (MEDEIROS, 2018), sendo a Invernada do Butiá a primeira a passar para o domínio do Incra para a implementação do reassentamento. Assim, embora a área contemplada pela fazenda Annoni fosse bem maior, comportando mais famílias, as dificuldades do Incra em ter sob seu domínio a fazenda Annoni em virtude dos trâmites legais que complexificaram a desapropriação levaram ao retardamento do assentamento dos afogados na Annoni, imóvel rural desapropriado para esse fim.

Assim, mesmo que essa ação já tenha sido sugerida anteriormente em função da "tensão social" arrolada no imóvel e das contradições representadas pelo latifúndio diante da existência de uma demanda local por terras, entende-se o surgimento de uma nova demanda por terras no estado como um importante elemento motivador da desapropriação. Ademais, a existência desses conflitos sociais e a necessidade de intervenção por parte de algumas lideranças da região ${ }^{10}$ demonstraram que a forma como o direito à propriedade na Annoni estava sendo exercido era passível de questionamentos, estando em dissonância com os anseios da coletividade.

\footnotetext{
10 Além das cooperativas que buscaram interferir enviando cartas ao presidente Médici, sindicatos de trabalhadores rurais, Câmara Municipal, e um Bispo da região estão entre aqueles que emitiram seus pareceres favoráveis aos arrendatários, e sugerindo a desapropriação do imóvel rural objeto de litígio instaurado entre eles e o proprietário.
} 
Foi nesse contexto que, após fazer levantamentos, o Instituto Gaúcho de Reforma Agrária (Igra) recomendou ao Incra a desapropriação da fazenda Sarandi-Annoni, levando em conta a existência de uma notável demanda por terras no estado e com base na necessidade de reassentamento de centenas de famílias que tiveram que sair das suas terras em função da referida obra. A construção da Usina Hidrelétrica do Passo Real, que ficou conhecida como uma das mais importantes obras de engenharia durante o regime militar no estado do Rio Grande de Sul, teve início ainda em 1965, sendo concluída em 1968, e resultou na remoção de centenas de famílias que viviam nas proximidades onde foi construída a barragem (SEMINOTTI, 2009, p. 134).

Antes disso, além da posse que foi objeto de disputa entre o proprietário e arrendatários, responsáveis pela maior parte da produção agrícola por serem mais capitalizados, dispondo de meios para investir na produção, havia relações de parceria com vinte colonos que trabalhavam na terra com suas famílias e residiam em pequenas colônias dentro do imóvel. Assim, se considerarmos os parceiros como potenciais beneficiários de lotes de terra, somando a existência na região de famílias sem-terra que não foram contempladas com os lotes da fazenda Sarandi, desapropriada por Brizola em 1962, pode-se afirmar que, no próprio imóvel e nas suas redondezas, havia uma demanda por reforma agrária que era anterior mesmo ao surgimento do problema dos afogados.

Para os parceiros que viviam no imóvel e trabalhavam naquelas terras, a distribuição de lotes seria a possibilidade de se tornarem proprietários e poderem trabalhar para si, se apropriando dos lucros do seu trabalho, ao invés de "trabalhar para os outros". Aos sem-terra ou com pouca terra na região, a reforma agrária contribuiria para a sobrevivência e a permanência no campo, tendo em vista que o êxodo rural era uma preocupação constante na época. Aliás, frear o êxodo rural é um dos motivos que fazem com que a reforma agrária ganhe força novamente nas pautas políticas na década de 1980, já que, com o êxodo rural intensificado nas décadas 1970 e 1980, o campo enviou para as cidades também parte de seus problemas (SILVA, 1985).

A desapropriação de um grande latifúndio parecia ser a solução imediata à demanda por terras que surgia com o problema dos afogados. E seria, não fosse a impugnação movida pela família proprietária, amparada no direito à propriedade requerido mediante a possibilidade de recadastramento do imóvel. Assim, mesmo ainda pleiteando na justiça a liberação integral do imóvel para fins de reforma agrária, o Incra conseguiu alocar algumas famílias em caráter provisório. Há divergências em relação aos números, mas, no laudo pericial, há referência a 55 famílias que vieram da região da Barragem do Passo Real. Transferidas para o imóvel cuja propriedade era disputada pela família proprietária e pelo Incra, as primeiras famílias que chegaram na Annoni receberam, tempos depois, a denominação de "parceleiros velhos", recebendo do Incra a autorização para cultivar uma "parcela" de terra.

Essas mais de cinquenta famílias passaram a viver no interior do imóvel, trabalhando na terra, sem, no entanto, dispor da sua propriedade, ainda disputada pelo Incra e proprietários. À mercê da 
morosidade que é própria das decisões judiciais mais complexas, o tempo foi passando e essas famílias permaneceram à espera de uma solução definitiva, que demoraria a chegar. Ao alcançar o status de empresa rural, pretendido pelos desapropriados, surge um novo impasse no processo judicial de desapropriação. Legalmente, por ser uma empresa rural, a Annoni não poderia ter sido desapropriada para fins de reforma agrária. Tal modalidade de desapropriação poderia incidir apenas sobre latifúndios. Havia, no entanto, segundo o Incra, um problema urgente a ser resolvido, que era a existência de muitas famílias removidas pelo poder público de suas terras e em situação precária, o que requeria dos tribunais um olhar diferenciado para a situação, já que, "bem ou mal", havia um projeto de reassentamento sendo desenvolvido no imóvel (DICKEL, 2017, p. 84).

Apesar das incertezas em relação à permanência na Annoni devido à complexidade que o processo desapropriatório adquiriu, uma vez que os desapropriados conquistaram o status de "empresa rural" para o imóvel, o que contribuiu para burocratizar ainda mais a desapropriação, essas famílias conquistaram o direito de permanecer no imóvel. Essa permanência das famílias fez com que, mesmo diante da questionada comprovação da classificação do imóvel como empresa rural obtida pela defesa dos desapropriados, dando ao imóvel imunidade à desapropriação, o Incra conseguisse levar adiante seu projeto de reassentamento, amparado no "princípio de não retrocessão", uma vez que a retirada das famílias acarretaria em mais problemas ao poder público.

Segundo o "princípio de não retrocessão", referenciado no processo de desapropriação da Annoni, se o poder público já estivesse desenvolvendo algum projeto no qual havia investido recursos públicos, a retrocessão na desapropriação implicaria prejuízos inaceitáveis. A compreensão de que o espaço se tratava de uma empresa rural levou a mudanças no procedimento administrativo, convertendo a "desapropriação para fins de reforma agrária" em "desapropriação indireta", uma vez que não houve desvio de finalidade, já que as terras estavam servindo, pelo menos parcialmente, ao fim que motivou a desapropriação (DICKEL, 2017, p. 84).

Isso, contudo, se deu de modo parcia, pois apenas uma pequena parte do grande latifúndio era ocupada pelos parceleiros do Incra, ficando o restante da fazenda na posse dos desapropriados, que relutavam em retirar o gado até que as partes não chegassem a um acordo em relação à indenização, que passou a ser pleiteada quando os tribunais decidiram pela não retrocessão na desapropriação, através de mudanças no procedimento administrativo, com a conversão em desapropriação indireta. Tem início, então, uma nova fase no processo judicial, em que o imóvel passa a ser avaliado para fins de indenização (DICKEL, 2017, p. 86). Enquanto isso, o gado permanecia ocupando a maior parte do imóvel, até que, em 1980, a região volta a efervescer em conflitos sociais tendo a terra como centralidade.

O estado, que já vivenciava o drama dos afogados - uma vez que apenas um pequeno número de famílias foi realocado na fazenda Annoni e em alguns outros assentamentos, restando um grande número de famílias à espera de uma solução -, passou a testemunhar o crescimento vertiginoso do 
contingente de sem-terra. Em 1978, ocorreu a extrusão dos colonos que haviam adentrado anos antes, das mais variadas formas, na reserva indígena de Nonoai no norte do estado. Nas palavras de João Carlos Tedesco sobre o conflito de Nonoai,

A luta social que devolveu boa parte das terras aos índios, produziu uma outra realidade de difícil resolução. As mais de mil famílias de pequenos agricultores expulsos da reserva de Nonoai não tinham para onde ir, milhares de sem terra ficaram a vagar pelas estradas na região de Nonoai, Ronda Alta e Sarandi. (TEDESCO, 2012, p. 254)

Essa expulsão colocou às margens da sociedade norte-sul-rio-grandense um contingente de pequenos agricultores, muitos dos quais saíram sem sequer conseguir trazer aquilo que haviam conquistado com seu trabalho. Algumas dessas famílias não aceitaram as alternativas propostas pelo governo, como os projetos de colonização no Mato Grosso, uma vez que dados do Incra revelavam a existência de terras ociosas no estado (MÉLIGA; JANSON, 1982).

A partir de reuniões e discussões, eles passam a questionar a desapropriação da fazenda Sarandi. Em 1962, uma parte das terras desapropriadas foi arrendada a empresas rurais. Assim, as granjas Macali e Brilhante se tornaram alvo dos sem-terra, que, após ocuparem e permanecerem na área, conquistaram o assentamento de mais de duzentas famílias em 1979 (MARCON, 1997). Entretanto, além de não resolver o problema dos sem-terra da região, uma vez que a demanda existente era bem maior, a ocupação deu vigor à ideia de que somente a partir da ocupação de terras seria possível mudar a realidade fundiária da região, e, consequentemente, amenizar a situação de miséria e exclusão social que acometia uma parcela considerável dos sem-terra da região.

Nesse contexto, o acampamento Natalino surge em 1981, às margens da RS 324, no município de Ronda Alta. Ele tornou-se um grande marco do ressurgimento da luta pela terra e retomada da organização dos camponeses, culminando no surgimento do Movimento dos Trabalhadores Rurais Sem-Terra (MST), que viria a ser considerado "o mais organizado movimento de luta pela terra no país" (FERNANDES, 2008). 0 acampamento Natalino teve início após a ocupação das granjas Macali e Brilhante, e as primeiras famílias que se instalaram ao longo da rodovia RS-324, que liga Ronda Alta a Passo Fundo, "eram proveniente da reserva de Nonoai e não haviam sido contempladas nos assentamentos nas Granjas Macali e Brilhante (MARCON, 1997, p.66).

0 desfecho desse acampamento que marcou a retomada da organização dos camponeses em prol da luta pela terra foi fundamental para que o MST começasse a se estruturar na região, a partir de núcleos de discussão relacionados à luta pela terra, nos municípios de Ronda Alta, Três Passos e Frederico Westphalen (MARCON, 1997). A partir de discussões nos núcleos, surge a posição entre os sem-terra de que a ocupação de terras por um grande número de famílias seria um importante elemento de pressão para a realização da reforma agrária, já que, pelas vias legais, mesmo prevista no Estatuto da Terra, a reforma agrária não havia sido implementada. 
Se a encruzilhada Natalino marcou o início da formação do MST, que surge em âmbito nacional e passa a se estruturar também em outros estados a partir do I Congresso Nacional, a ocupação da fazenda Annoni foi fundamental para que as ideias do movimento começassem a ser colocadas em prática. Despertar a atenção da sociedade para a situação de miséria e exclusão social daqueles que reivindicavam terras para trabalhar, enquanto a desapropriação de um grande latifúndio esbarrava em trâmites burocráticos permeados por decisões judiciais que favoreciam os proprietários da terra, foi um dos objetivos da ocupação organizada pelos sem-terra em 29 de outubro de 1985 (DICKEL, 2017).

A contradição representada pelo grande contingente de marginalizados no campo e a existência de terras que poderiam garantir a sobrevivência de muitas famílias são fatores que contribuem para que alguns setores da sociedade passem a olhar com mais sensibilidade para o drama dos sem-terra, que deixam a invisibilidade e assumem o protagonismo para reivindicar melhores condições de vida. No intuito de deixar claro quais eram as intensões dos acampados, além de manifestações e caminhadas, foram produzidos, ao longo dos meses em que durou o acampamento na Annoni, boletins, cartilhas e outros documentos. A situação provisória que caracterizou o grande acampamento se deu em função do litígio judicial, cujas indefinições impediam a destinação da área para fins de reforma agrária.

Esses novos sujeitos que ocuparam a Annoni em 29 de outubro de 1985, provenientes de 33 municípios próximos dali, eram filhos de pequenos agricultores, meeiros, agregados, parceiros e trabalhadores rurais, e passaram a reivindicar a reforma agrária, pressionando a liberação da área em litígio desde o início da década de 1970 (GOES, 2010). Em comum, a conquista de um lote de terra como possibilidade de continuar trabalhando e vivendo no campo, uma vez que a ida para a cidade dificilmente traria a possibilidade de uma vida digna. 0 desejo de dar uma vida melhor para os filhos e de sobreviver da agricultura foi o que motivou milhares de pessoas a manterem-se unidas, em detrimento das diferenças e das dificuldades passadas.

Assim, passados praticamente dois anos da ocupação, após decisões judiciais que determinaram a remoção do gado da família desapropriada, que ocupava uma parte do imóvel, aos poucos, a Annoni foi sendo liberada pelo Incra para servir de assentamento. Além das mais de quatrocentas famílias alocadas dentro do antigo latifúndio, o acampamento da Annoni deu origem a vários outros assentamentos em outras regiões do estado, para onde foram muitas das famílias, já que o imóvel não abrigaria a totalidade dos acampados. E, desse modo, configurou-se o assentamento na Annoni, confluência de diferentes lutas individuais e coletivas em prol de uma divisão mais igualitária da terra, tornando-se um grande marco da reforma agrária no Brasil.

Assim, esse expressivo grupo de sujeitos acometidos pelos efeitos de uma estrutura fundiária que, ao mesmo tempo, concentra e exclui, se encontrou no grande latifúndio, no qual, em meio a pequenas propriedades onde mal dava para se viver, prosperava muito capim-annoni, espécie 
invasora que era cultivada na fazenda, de baixo valor nutritivo para o gado (CORREA, 2012). E é dessa forma que os camponeses, expropriados pelo capital, se territorializam através da luta pela terra, ao mesmo tempo em que reconstroem o capital a partir da sua produção com o assentamento (FERNANDES, 2008). E foi lá que sujeitos que vivenciaram processos históricos distintos em relação à posse e à propriedade da terra resistiram, tentando recriar ou pelo menos manter vivo o seu modo de viver e se relacionar com a terra.

\section{CONSIDERAÇõES FINAIS}

Este texto teve como proposta buscar contemplar o processo histórico que antecedeu e permeou a desapropriação da Annoni, contribuindo para sua consagração enquanto palco por excelência de disputas de direitos envolvendo a posse e a propriedade da terra. Desde o início da década de 1970, o imóvel já era palco de uma tensão social, permeando as relações sociais entre o proprietário e seus arrendatários, com o passar do tempo, o caldo de conflitos é engrossado, com a inclusão de novos sujeitos que passam a protagonizar as disputas pela terra na Annoni.

Constatou-se, ao longo do trabalho, que a existência de um grande latifúndio em uma região com uma predominância de minifúndios como característica marcante da estrutura fundiária possibilitou que a forma como o direito à propriedade estava sendo exercido pudesse ser questionada. Na medida em que as propriedades cada vez menores deixam de garantir a sobrevivência das famílias, impossibilitadas de ocuparem novas terras na região diante do fechamento da fronteira agrícola, e o contingente de sem-terra cresce vertiginosamente, o latifúndio passa a representar uma contradição, e a propriedade, um direito a ser questionado por setores da sociedade.

Ademais, considerando-se o contexto da virada da década de 1960 para 1970 e a existência de um processo de modernização em curso, trazendo mudanças naquele modelo tradicional de agricultura com a adoção de novos sistemas de cultivos e a importação de um verdadeiro pacote tecnológico a ser utilizado no campo, com a sobreposição da pecuária pela agricultura, a propriedade que não se modernizasse seria passível de questionamento, não apenas pelo governo, pela legislação, mas pela própria sociedade, que passa a ver o latifúndio como um entrave ao desenvolvimento, e sinônimo de atraso.

No caso da Annoni, mas que também se aplica ao latifúndio de um modo geral, a apropriação privada de grandes extensões de terra insuficientemente ou mal aproveitadas pode ser vista como um instrumento de exclusão social, pois a sua existência desconsidera o grande contingente de indivíduos dispostos a trabalhar a terra, e, por não disporem dela, veem-se excluídos na sociedade. Portanto, não foi por acaso que a reivindicação de uma distribuição mais igualitária das terras como instrumento de trabalho e reprodução social camponesa encontrou terreno fértil na Annoni. No final da década de 
1980, após a grande ocupação organizada pelo MST em 1985, esses diferentes sujeitos partilhavam do mesmo desejo, que, ao longo do tempo, na condição de colono parceiro, parceleiro, afogado ou semterra, protagonizaram, cada um ao seu modo, a luta pela democratização das terras da Annoni.

\section{REFERÊNCIAS}

ALVES, B. J. P. A política agrária de Leonel Brizola no Rio Grande do Sul: governo, legislação $e$ mobilização. Mestrado em Programa de PósGraduação de Ciências Sociais em Desenvolvimento Agricultura (Universidade Federal Rural do Rio de Janeiro, UFRRJ, Brasil) 2010.

ALVES, Clóvis Tadeu. A Revolução Verde na mesorregião noroeste do RS. Dissertação (Mestrado em História). Universidade de Passo Fundo, 2013

BONAVIGO, Elisabete Ana. BAVARESCO, Pedro Antônio. Fazenda Annoni: da ocupação ao assentamento definitivo. In: TEDESCO, João Carlos. Conflitos agrários no norte gaúcho-19802008. Passo Fundo: Ediupf, 2008.

BRUNO, Regina. Senhores da Terra, Senhores da Guerra. (a nova face política das elites agroindustriais no Brasil). Rio de Janeiro: Forense Universitária: UFRRJ, 1997

CORREA, S. M. Silvio. A Africanização da paisagem rural do Brasil meridional: uma intersecção da história agrária com a história ambiental. In: II Encontro do GT História Agrária, 2009, Porto Alegre. Anais do II Encontro do GT História Agrária. PortoAlegre,2009. Itajaí: Casa Aberta, 2012.

DICKEL, Simone Lopes. Terras da Annoni: entre a propriedade e a função social. Curitiba: Editora Prismas. 2017.

FERNANDES, B. M. A formação do MST no Brasil. Petrópolis-RJ: Vozes, 2000.

Conflitualidade e desenvolvimento territorial. In: Antônio Márcio Buainain. (Org.). Luta Pela Terra, Reforma Agrária e Gestão de Conflitos no Brasil - Coleção Instituições, Agricultura e Desenvolvimento Sustentável. 1ed.Campinas: Editora Unicamp, 2008.

FICO, Carlos. O golpe de 1964: momentos decisivos. Rio de Janeiro. Editora FGV, 2014.

GEHLEN, I. Uma estratégia camponesa de conquista da terra e o Estado: o caso da Fazenda Sarandi. Dissertação (Mestrado em Sociologia) UFRGS, Porto Alegre: 1983

GOES, Valdemar da Silva. Entre cruzes e bandeiras: a Igreja Católica e os conflitos agrários no norte do Rio Grande do Sul (1960-2009). 2010. 145 f. Dissertação (Mestrado em História) Universidade de Passo Fundo.
LORENZON, Algir (Org.). Afogados: Até quando? Relatório da Comissão Especial dos Agricultores Desalojados do Passo Real. Porto Alegre: Assembleia Legislativa do Estado do Rio Grande do Sul; Companhia Rio-grandense de Artes Gráficas. S/D.

LUZ. Valdemar $\mathrm{P}$ da. Curso de direito agrário. Porto Alegre: Sagra-dc Luzzatto, 1996.

MARCON, Telmo. Acampamento Natalino: história da luta pela reforma agrária. Passo Fundo: Ediupf, 1997.

MACHADO, Ironita A. Policarpo; GERHARDT, M. (Org.); TEDESCO, João Carlos (Org.); KLUG, J. (Org.); NODARI, E. S. (Org.); NEUMANN, R. M. (Org.); RENK, A. (Org.); WINCKLER, S. T. (Org.). Indígenas, quilombolas e agricultores: história e conflitos agrários no sul do país. 1. ed. Passo Fundo: Editora Universidade de Passo Fundo, 2018.

MEDEIROS, P. V. S.. A Questão Agrária no processo de construção da barragem do Passo Real. In: XIV ENCONTRO ESTADUAL DE HISTÓRIA ANPUH/RS DEMOCRACIA LIBERDADES UTOPIAS, 2018, PORTO ALEGRE. Anais [do] 14 Encontro Estadual de História da ANPUH-RS, Porto Alegre, 24 a 27 de julho de 2018 [e-book]., 2018

MÉLIGA, Laerte Dorneles \& JANSON, Maria do Carmo. Encruzilhada Natalino. Porto Alegre, Vozes/Escola Superior de Teologia São Lourenço de Brindes. (1982)

RAMOS, Carolina. A Confederação Nacional da Agricultura e o Estatuto da Terra: embates $e$ recuos. Revista História e Luta de Classes. Ano 5, edição no 8, novembro de 2009.

SEMINOTTI, Jonas José. 0 movimento dos atingidos por barragens no norte do RS - 1979-2007. in: TEDESCO, João Carlos; CARINI, Joel João. Conflitos agrários no norte gaúcho, 1980-2008. EST Edições. Porto Alegre.

SILVA, Jose Graziano da. Para entender o Plano Nacional de Reforma Agrária. Brasiliense, São Paulo. 1985.

TAVARES, Elaine. Porque é preciso romper as cercas. Miembipe. Companhia dos loucos. 2009

TEDESCO, João Carlos. O "CONFLITO DE NONOAI": UM MARCO NA HISTÓRIA DAS LUTAS PELA TERRA NO RIO GRANDE DO SUL - 1978-1982. 
REVISTA DE HISTÓRIA [26]; João Pessoa, jan./jun. 2012.

WENTZ, Liliane Irma Mattje. Os caminhos $d a$ madeira: região norte do Rio Grande do Sul
(1902-1950). Passo Fundo: Ed. Universidade de Passo Fundo, 2004. 